\title{
MAJELIS TA'LIM AS SOCIALIZATION MEDIA OF CHILD PROTECTION IN WEST SULAWESI
}

\author{
Abdul Rahman \\ STAIN Majene \\ Jl. Balai Latihan Kerja Majene, West Sulawesi, Indonesia Country \\ Email:arahmanmks@gmail.com \\ Anwar Sadat \\ STAIN Majene \\ Jl. Balai Latihan Kerja Majene, West Sulawesi, Indonesia Country \\ Email: anwarsadat@gmail.com
}

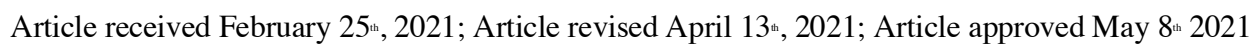

\begin{abstract}
The enactment of Law No. 35 of 2014 concerning Child Protection is intended to protect children and guarantee their rights to live, grow, develop, and participate optimally following human dignity and get protection from violence and discrimination. It could be achieved through increasing awareness of the rights and obligations and the responsibility of the involved parties, especially parents because they are the first and foremost in contact with children. In the context of the Law socialization, research is needed to find an appropriate and effective socialization model especially for women (mothers) through religious-social activities. One of them is majelis ta'lim program. This research used a normative-empirical research type. Normative research was used through the interpretation of grammatical and authentic legal methods. Empirical research was conducted by a teleological interpretation method to know the extent of the legal norm according to the community's attitudes, behaviors, and compliance. Data were collected through the study of literature and empirical studies using interview guidelines and questionnaires. The research results showed that the developed socialization model could solve the most fundamental and urgent literature and the wider community's interests. In protecting the community-based program, the issue is not merely children in conflict with the law. It includes a larger unit of interaction, such as parents, family, peers, environment, and wider social institutions
\end{abstract}

Keywords: Use of majelis ta'lim, Socialization of Child Protection

\section{INTRODUCTION}

$\mathrm{C}$ hildren are the future of a family, community, nation, and country. Without children, there is no future for anyone. Therefore, ignoring the quality of life of children is the same as not paying attention to the regeneration of family, community, nation, and country. When born, children give full confidence to parents to care for themselves. Also, children put the same expectation on other adults in their environment, the school environment, and the community. They believe that no one will hurt them. However, in various media lately, it is almost inseparable from the reporting of violence against children. Some often experience various forms of violence and exploitation of physical, psychological, economic, and commercial sexual exploitation.
The increase in violence against children every year, both in quality and quantity, causes the declaration of the National Commission for Child Protection in 2013 as a year of alert for crimes against children due to increased cases of crime involving children, as perpetrators and victims. In 2017 there has been an increase in sexual crimes against children in the past three years. Based on reports of violence against children in 2016, Indonesian Child Protection Commission recorded 2.046 cases (Republika.co.id 2014).

Of these, $42 \%$ were sexual crimes In 2018, 2.509 cases of sexual children sexual violence were $58 \%$. And in 2019, It continued to increase to 2.637 cases where $62 \%$ are sexual crimes. Such data shows the increasing cases of violence on children, specifically the higher number of sexual crimes. So besides increasing the number of cases of violence 
against children, sexual crimes are even higher.

Prostitution, pornography, and child trafficking have been a phenomenon for quite a long time in Indonesia. Referring to the dat a of the ICPC, 150,000 Indonesian children are prostituted and trafficked for sexual purposes (Kompas 2008). The data shows the increasingly widespread practice of commercial sexual exploitation of children (CSEC) in Indonesia.

Even more alarming than this child case is 80 percent. Sexual violence occurs in the household environment by closest people, such as an uncle, foster father, uncle, and even parents. Therefore, for some children, their houses are no longer comfortable places to get protection. From this fact, $90 \%$ occur in girls, and $82 \%$ of sexual violence cases tend to occur in the lower and middle economic class. Almost $100 \%$ of the perpetrators are uppermiddle-class people (Kompas 2008).

Such conditions are contrary to the provisions of Article 26 paragraph 1 of Law No. 35 of 2014, concerning Child Protection which states that "parents are obliged and responsible for: (a) caring for, educating, and protecting children; (b) developing children according to their abilities, talents, and interests; (c) prevent early marriages; and (d) provide character education and instill the value of character in children. Responding to the various child cases, the government has initiated child-friendly city programs as a form of government intervention and responsibility in realizing the protection of Indonesian children.

To socialize the law on child protection, we need a model called majelis ta'lim activities. This model is considered the most appropriate and effective way to socialize the law because activities in the majelis ta'lim are routine in almost all mosques and mushollahs, usually coupled with a mothers' social gathering. Members of the majelis ta'lim are parents who have the obligation and responsibility to care for, maintain, educate, and protect children (as stipulated in Article 26 paragraph 1 of Law No. 35 of 2014). They play a role in preventing various forms of children's violent practices that tend to be increasingly concerned with a consistent increase in almost all regions.

The escalation of this case should not merely attract people's concerns. Concrete prevention must immediately take into account to reduce such cases. Therefore, it is expected that after getting the socialization, the majelis ta'lim members can also participate in socializing the child protection law. Therefore, many parents will better understand the children's rights and obligations that all parties must carry out by in protecting and growing the body and soul of children in a conducive atmosphere (Muslim, 2011: 125-132).

The majelis ta'lim activities are in almost every Mosque and mushallah in West Sulawesi, where the community is known as a religious community. It makes the socialization program reaching the target easily in all society levels, especially mothers. Now, there has not yet been seen an appropriate and effective guideline or model for socialization. The socialization activities are usually only carried out in PKK meetings, and there are no forms or guidelines for their delivery.

\section{LITERATURE REVIEW}

In the framework of child protection, almost all studies on the violence against children issue focus on disclosuring the causes, modes, and role of the government in protecting children. However, research on the central role of parents in educating and providing child protection is still very limited (not to say there is not yet).

\section{The Legal Basis For Child Protection}

The Indonesian people should pay serious attention to the protection of children because the mandate of the 1945 Constitution Article 28B (2) states that "Every child has the right to survive, grow, develop, and be protected from violence and discrimination". Then, Article 33 of Law no. 39 of 1999 concerning Human Rights regulates that "Everyone has the right to be free from torture, punishment, or inhumane, cruel treatment, degrading human dignity and status". Also, Article 52 (1) states that "Every child has the right to be protected by parents, family, community, and country ". Ironically, according to the research results of Hadi Setia Tunggal (2000: 10), in Jakarta, 92\% of 400 government officials did not recognize the existence of such rules in the Convention on the Rights of the Child (CRC). 


\section{The Cause Of Violence Against Children}

Several factors that often trigger the violence against children include (a) Culture; where children are being considered familyowned and the successor line of the family, who must follow the rules made by the family. (b) Government law and political commitment do not favor children; Several advancements of the implementation of the CRC during the New Orde and Transitional Governments should be recognized, but unfortunately, these advancements are still limited to political slogans. They are not followed up in the real programs that protect the children's rights in all work fields.

Childhood is a period of play, love, learning, growth, and development. However, children in Indonesia indeed experience this phenomenon. Another fact, according to Irwanto (2002: 2), in the education sector, it is estimated that around 17.5 million school-age children will drop out of school because they are forced to work to help their parents make a living.

\section{Forms Of Violence Against Children}

According to Gelles (in Bagong Suyanto, 2013: 15-16), acts of violence or violations of children's rights can be categorized in at least four forms: (1) Physical violence; This violence is easily recognized, such as slapping, kicking, punching, strangling, pushing, biting, banging, and threatening with sharp objects.

(2) Psychic violence; The impacts of this violence are feeling insecure and uncomfortable, reducing self-esteem and dignity of victims. Examples of this violence are harsh words, abuse of trust, humiliating people in front of others or the public, and throwing threats of words. Victims will usually feel inferior, worthless, and weak in decision-making. Lately, there has been a lot of news about violence against children. Some children are beaten, doused with hot water, even body ironed. That fact is serious and strengthens the perception that violence against children cannot be resolved, even with the rule of law and legislation.

(3) Sexual violence; Sexual violence is any act that involves sexual harassment to compel a child to have sexual relations without his consent or engage in ways that are not nat ural or preferred by the victim. Sexual violence is also the sexual assaults on children, without regard to the relationship between the perpetrator and the victim, or forcing the child to prostitute or have sexual relations with others. (4) Child neglect; Leaving children neglected or not caring about children, while they need parents to meet their needs. Another violence is also experienced by children, such as the sale of children for commercial purposes.

In Indonesia, violence against children has been entrenched and carried on for generations. As a result, cases of violence against children continues to increase every year. One of the triggers is poverty or economic difficulties faced by parents. However, these factors are not the only factors triggering violence against children. Violence against children is closely related to cultural and structural factors in society. In cultural factors, for example, the opinion that children are the parents' assets or children must be obedient to parents seems to be a justification for acts of violence against children. If the child is considered negligent, fussy, disobedient, and against their parents, he will get sanctions or punishment, turning into violence.

Structural factors include unequal (asymmetrical) relationships within the family and community. In this context, children are in a weaker and inferior position because they are physically weaker than adults and still depend on their adults.

Parents' Obligations Under Law No. 35 of 2014

Parents, as the closest person to the child, are obliged to carry out their obligations. Parents must not only claim rights to children but also have obligations. In Law No. 35 of 2014, parental obligations are listed in article 26 which states: "Parents are obliged and responsible for: (a) caring for, educating, and protecting children; (b) developing children according to their abilities, talents, and interests; and (c) prevent early marriages.

\section{RESEARCH METHOD}

The approach used in this research is explorative and qualitative. The exploratory approach is used to get a comprehensive initial overview of the policies of a program while the qualitative approach is used to obtain a rich description of nuances, feelings, and 
thoughts related to the research problem. Regulations on violence and protection of children and groups / majelis ta'lim are study materials that will be analyzed and grouped to find indications that are specific to the problem to be examined.

To obtain the required data, observations, interviews, and questionnaires will be carried out. Observation (preliminary) was conducted to determine the condition of the study area for assessment and data collection on matters relating to acts of violence against children with demographic characteristics and a general description of the population. In-depth interviews were conducted with several trusted informants who were selected by purposive sampling. Interviews were conducted using an interview guide that was compiled in a list of questions that had been prepared. This is intended so that researchers can freely develop questions for informants and an atmosphere of an interview can be built that is not more formal. The questionnaire was conducted by distributing questionnaires to the majelis ta'lim groups through the chair of the majelis ta $\lim$ in each research location. Besides, library research is also conducted to obtain a theoretical reference base in the form of opinions and input from parties deemed competent and authorized.

\section{DISCUSSION \\ Characteristics Assessment of Children Facing Law}

The main concern in protecting children is the child's growth and development to grow and develop properly. Children who are protected adequately will become a qualified generation needed by the nation and state in the future. Children in conflict with the law (CCL) is a social problem caused by not only children as the internal factor but also many external factors that make children commit crimes. The assessment is divided into three groups: the child's developmental needs, caring capacity, and family and environmental factors (Holland 2014).

Personal, family, and social factors are the causes of children's delinquency. The transactional model introduces them between children and many relationship contexts that affect children's development (Davies 2011). In West Sulawesi, based on the results of this study, those internal and external factors make children do unlawful acts or deal with the law.

First, the child lacks education, especially moral education, which shapes the child's characteristics. Therefore, school plays a critical role because it has a meaningful influence on children's development and provides the right of every child to be educated. Second, family factors are very important for children's development because, according to CCL data, one of the causes is family factors. Families become problem solvers. Seven intervention models can be developed (Setiawan and Makmur 2015)

The lack of economy in a family also causes less care for children. They tend to develop their character that is different from the society norms and ultimately confront the law. Many delinquents come from a case of violence in the family. This study considers that the family approach in completing CCL is effective in the child welfare system.

Third, peers are also the important party that must be considered because their effect is very large for the child, and even the effect can be greater than the family. Peers are people of the same age or maturity level. Fourth, the community environment is very important for children's development. Most often, the community refuses the cases of CCL and other cases of child problems. If the public awareness about child protection is high, then the child should be protected and guided to grow and develop according to his age (Setiawan and Makmur 2015)

One of the best approaches for preventing future aggression problems in children is to intervene early on (A. Woolfolk, 2009). There is also a concern for children who play video games, because playing games, especially violent games, can increase one's aggressiveness. In addition to the family approach, an ecological approach can also be used in overcoming the problem of sexual violence. On other issues, drug use will cause children to commit crimes (Setiawan and Makmur 2015).

CCL's problems cannot be separated from problems in the surrounding environment. Without ignoring other approaches, researchers used a socialecological perspective in developing a community-based approach model. This approach focused on children in conflict with 
the law who live in Polewali Mandar District. Interventions were also carried out on other significant parties, including parents, the community, peers, and schools. In the majelis ta 'lim approach, several components are met: the individual victim, the offender, and the community (Mohan 2010)

The model of socialization through the majelis ta'lim is considered the most effective alternative. First, members of the majelis ta'lim are mostly mothers and a small number of fathers who have the main responsibility in protecting their children. Second, members' gathering in the majelis ta'lim is easy to conduct socialization because they just have to follow the recitation schedule, which is held routinely every month. Third, the Mosque can be used as a place for socialization. Fourth, the majority of members of the majelis ta'lim have close attention and awareness to children. Taking into account the condition of CCL in Polewali Mandar District, this approach through the majelis ta'lim needs to be developed with aims:

1. Disseminating Law Number 35 of 2014 concerning Child Protection.

2. Give parents greater awareness of their duties and responsibilities in educating and protecting their children.

3. Raise the awareness of mothers as parents in particular and society in general about children's rights.

4. Assist parents in identifying needs and organizing for children to meet their needs.

5. Developing the capabilities of children and their parents to understand and act based on the ability to use internal and external resources to meet their needs and overcome problems.

The relationship between children, peers, family, and community is close, the child is part of the family, and the family is part of the community. Departing from this conception, the planned program must at least include programs for children and their environment. First, the Families Program is a strategic position for the child's personality development. The ideal family will generate the ideal child's personality and will ultimately realize the ideal future of society and the nation. Second, the Peer Program is critical in shaping children's development. The program can be peer support. Third, the Education/School Program, because it will shape the development of children. Fourth, the Community Program, which constructs the perception to be always on the children's side.

The CCL problem is multi-factor, consisting of internal and external factors. Internal factors consist of cognitive, affective, behavioral, volitional, and personal/social identity. While external factors consist of circumstances, location, opportunities, resources, support, dan program/timing factors (Ward, Hernández-Sánchez, and Sánchez-García 2019)

The community-based approach through majelis ta'lim aims to form a society with high social cohesion by maintaining a local culture as the basis for social and economic progress. Such a society can produce superior products, have competitiveness, master practical science and technology, and have a high commitment and fighting spirit to improve their welfare. Basically, there are 4 strategies in the corrective system in preventing crime, including incapacitation, prison-based therapeutic communities, specific types of educational and training programs, and nonprison-based sex offender treatment that have been consistently identified in recidivism reduction (Golder et al. 2005).

Thus the handling of CCL through the majelis ta'lim has three main functions: to prevent, recover, and create restorative justice. Many community organizations commonly carry out the stages of community development: "Preparation phase, assessment, alternative planning, formulation of action plans, implementation of programs or activities, evaluation and termination (Adi 2013).

This problem is part of the social work profession, which is one of the rescue professions. Social work is a relief activity for individuals, groups, or communities to improve social functioning and create conditions that support society to achieve their goals. The basic aim of this approach is to help parents find their needs and carry out their responsibilities and improve their functioning, including reintegrating CCL with their families and communities. The correctional principle in Indonesia, which was coined in 1963-1964, is a philosophy of social reintegration (Sulhin 2011). Reintegrate offenders into society aims to achieve a restorative justice system. 


\section{Handling and Protection Models of Children in Conflict with the Law}

The definition of a child is under 18 years old as agreed in the Convention on the child's right. Children who are dealing with the law are individuals with all aspects of their development. They must interact with others in their social environment and influence each other. Ecological models become a scope of external development and contribute to the concept of individual development. According to Bronfenbrenner's ecological model, a child is influenced by the structure of the environment in which he lives, which consists of: "microsystem, mesosystem, exosystem, macrosystem, and crony system." The problem experienced by children dealing with the law occurs when the child returns to the family, peers, and the surrounding community. In detail, the programs applied in Polewali Mandar Regency are as follows:

\section{Model Concept}

The process of social intervention, which helps CCL, includes several aspects of fulfilling needs, such as capacity building, the realization of aspirations and values, control and elimination of tension, facing or overcoming difficulties, or problem-solving. Social workers must influence others to be willing to follow suggestions for a better life, noting that the right to change is in the concerned person. The developed principle of helping is to help someone to help themselves (help people to help themselves).

An approach through majelis ta'lim is a kind of community-based program. In general, the purpose of community-based programs is to realize the children's basic rights fulfillment and children protection from neglect, violence, exploitation, and discrimination so that children can grow and develop, ensure their survival, and participate in the realization and fulfillment of their rights. The ecological approach will pay attention to the interactions between factors at various levels of an ecological influence and how they shape the behavior of individuals and their environment (Dutton 2002).

The developed CCL handling model is expected to: First, prevent (preventive) so that children are not facing the law. Second, returning (reintegrative) childcare functions to parents so they can carry out properly. Third, return the child's social function to develop (promotive) following the task of development at his age. This program is participatory, sustainable, empowering, multiplier, and social control.

According to Bronfenbrenner's view, children dealing with the law are not merely the product of development. They are the building blocks of development. This intervention is not only for CCL but also for larger interaction units: parents and children, the whole family, and the neighborhood. The model that results from the implementation of the socialization program through the majelis ta'lim can be seen in the following chart:

Chart 1

Child Handling Model in Facing the Law Through the Islamic Board

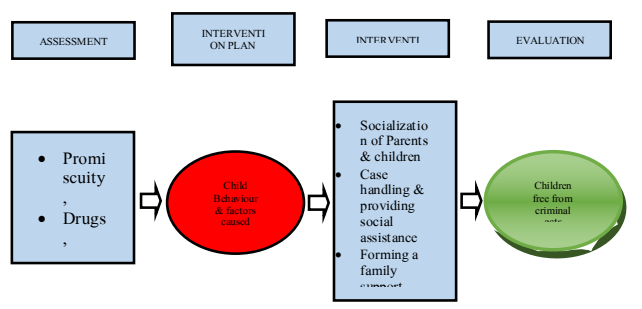

The developed model of the socialization program must at least include targets for children and their environment. First, the socialization for the community and children is intended to raise the awareness of the community and children about CCL problems in their environment. Second, handling cases and providing child social assistance, are the steps and interaction processes in one service network to ensure that CCL gets comprehensive, competent, effective, and efficient services. Third, the formation of family support groups is important for the implementation of interventions against children. Fourth, the formation of peer support groups is important for the implementation of interventions against children. Group formation is also important because peers have a very strong influence on children's development. This socialization model is expected to realize the service goals, namely "The Best Interest for Peer Support".

\section{Operationalization of The Model \\ 1) Socialization to Parent and Children}

This activity was intended to raise public awareness about CCL issues in children's environments. Socialization to 
parents was carried out through the majelis ta'lim activities in the Mosque, assuming that the majelis ta'lim is the most effective place and runs routinely on an ongoing basis. In the beginning, if there was a CCL case, the community tended to judge and hand it over to the police. If the child reaches the police, the problem is not over. Children are psychologically traumatized, so they don't go to school. Especially if the child is labeled as the "evil" in society, this label causes children to be exclusive and most likely to rejoin negative playgroups. Therefore, the community is expected to have a better understanding and behavior of parents and children.

This activity was carried out in Mosques, often also attended by several husbands who diligently attended religious studies. The speakers in this socialization activity were researchers and religious teachers who brought the study sessions and included employees from the Polewali Mandar District social service. Religious lectures related to the duties and responsibilities of parents in educating and protecting their children were carried out first, then followed by socialization on the child protection law by explaining the duties and responsibilities of parents. It was according to the law and the procedures for handling, in the case of CCL and children's rights related to legal proceedings. The socialization always received positive responses from members of the majelis ta'lim who were parents.

Accessibility is a factor causing child criminal behavior. The ease of getting drugs and even initially being given free is a condition/a potential factor for a child to commit a crime. Based on research conducted by (Rosen 1994), the percentage of perpetrators of violence due to consuming alcohol is $86 \%$. From these data, $37 \%$ are rape perpetrators, $60 \%$ are free sex offenders, and $13 \%$ are perpetrators of child abuse (Klostermann and Fals-Stewart 2006). Other studies say that for someone with a history of using alcohol, 30-60\% increase aggressive behavior syndrome. This behavior includes skipping school, fighting, and teasing (Chen et al. 2008)

Thus, in addition to users and traffickers as perpetrators of crime, drugs can also trigger other or subsequent crimes. Besides drugs, the media can also cause delinquency among children (Laser and Nicotera 2011)

Socialization to children is also usually applied by inviting children through activities "Children Talent Competition" (CTC). In this study, it was not done considering the limitations of cost and time. There was a drawing competition and a music competition through a Group Band in this kind of socialization. The theme of this activity was "preventing children from being involved in conflicts with the law". This activity is to positively channel the interests and talents of children so that children do not have much time to think about or do negative things. These activities involve children from planning to implementation to truly express all their ideas or aspirations and potential, especially in arranging a program or activity.

\section{2) Handling Cases and Providing Social Assistance for Children.}

In practice, social work is known as case management, which is the steps and processes of interaction in one network service to ensure a child or vulnerable group receives comprehensive, competent, effective, and efficient services. Case management is a method for providing a variety of services. A case manager assesses the needs of children and their families as needed and designs, coordinates, advocates, monitors, and evaluates various services to meet the specific needs of children. The stages of CCL case management include: 1) outreach, 2) initial acceptance, 3) assessment, 4) service plan, 5) implementation and supervision, 6) reintegration and follow up, 7) networking and coordination, 8) case recording, 9) monitoring and evaluation, 10) termination, 11) continued service.

Children in conflict with the law (CCL) in Polewali Mandar District received 15 social assistance. The use of social assistance was planned by children and parents together with social workers. Most children planned their programs in education, formal and non-formal education. Children who were helped were endeavored to enter formal school. Children who wanted to get a diploma but were not allowed to enter the formal school age, then sought through education $\mathrm{A}, \mathrm{B}$, or $\mathrm{C}$ packages to gain a diploma that is equivalent to formal schooling. Some children joined work skills 
courses. The children's needs were planned based on their goals and needs.

\section{3) Formation of Family Support Groups}

Activities are based on the number of families who do not support children when experiencing legal problems. Family acceptance is very important for the implementation of interventions against children. In line with this, experienced families risk violence or neglect of children who need assistance developing their functions, eliminating the risk of abuse, and preventing children from leaving home (Hearn 2010). Through good care, it will impact the development of their children because there is a relationship between early care with the child's academic ability (Burchinal, Vandell, and Belsky 2014)

The problems of CCL parents include the economy and family care. The provided programs are: first, increasing family income in a cooperative container that can help provide venture capital. At present, it is pioneering cooperative activities in selling cheap goods regularly once a week. Second, family guidance for those who have problems with children, wives, and husbands is expected to be a good family. This can be done through counseling and regular study of harmonious families, obligations of husband and wife, and children consulting various other family problems.

Third, the program provides education and knowledge useful for behavioral change in their lives in studying social guidance, discussion, and others. Fourth, the health service program by providing health information and referrals to hospitals for the community. If they are experiencing health problems, treatment information is very difficult. They do not know where they should seek treatment if the family member is sick, how the process is, and the use of health cards.

Fifth, a support group is an approach and cooperation formed by themselves to discuss and solve their problems, particularly when they have been busy with their respective jobs and affairs. By using this group, they can be better and livelihood mutual respect. Sixth, family strengthening is to strengthen the family foundations that have been experienced by many of them. At the same time, they are not aware and do not know the meaning of a family for their children, so they no longer take action against the law.

\section{4) Formation of Peer Support Group}

This activity is important because peers are one of the social environments that affect children's development. The accompanying social worker carry out outreach. Sometimes they found obstacles because of differences in age and life background. To be more effective and more empowering outreach, a peer support group (KDS) was formed to overcome these problems. KDS is a model for building relationships with someone in recovery (Walker and Bryant 2013). The purpose of peer support groups is to share ideas, suggestions, and advice to provide support (Maguire et al. 2008).

Effective outreach and mentoring strategy were carried out through peer to peer approach, training the first ten people to become peer groups who will explain to their fellow friends about their existence and towards a better life. Outreach and assistance carried out by peer support groups at predetermined locations are effective strategies in the social services to children. In line with this opinion, the peer group can be manipulated to overcome the problem of antisocial behavior, namely bullying (Garandeau and Cillessen 2006)

The manipulation in question was not to eliminate the group of friends but to change the group of friends with positive activities. In assisting, peer support groups mingled with children in children's activities. In the process, peer support groups understood the identified children. This strategy was more effective because children could be more open with peer support who were considered like their friends/siblings. Provided assistance was expected to change the mindset of children. In this activity, peer support groups directed and motivated children to participate in further activities.

Such activity aims to create positive creativity. Through this activity, peer support groups gain trust in their lives and talk about their fut ure lives. After attending the training, KDS agreed to make an organization as a communication channel in reaching out to friends and an effort to develop positive creativity. 
Peer groups are considered effective because they are more open, so they are expected to find out the real problem and find the best solution. On his journey, many interesting experiences could be a reference for peer support groups in the fut ure. So they need peer support training to explore their experiences. Therefore, it is necessary to be equipped with various related knowledge and skills through training. In CCL, the peer group is believed to influence children to change aggressive and anti-social behavior (Gibbs et al. 1996)

\section{CLOSING}

The description of CCL characteristics can be traced from several cases carried out by child informants who are CCL perpetrators. During the study in Polewali Mandar District, 4 cases of children's problems were found, including intercourse, drugs, theft, and brawl. The factors causing them to commit the crime are not only from the children themselves but also closely related to other factors such as the environment. The environmental factors that cause children to commit criminal acts in Polewali Mandar Regency include family, peer influence, negative community stigma, and accessibility to the causes of criminal behavior. The lack of socialization in the community regarding this problem is also a cause of children's problems.

The developed program should concern the CCL's problems that are closely related to the environment around children, so it is important to develop comprehensive interventions in solving problems. One of the community-based approaches is through the majlis ta'lim. It is used to explore and foster community participation in finding problems and needs, planning activities, participating actively, and overseeing the implementation of activities.

The effectiveness of the developed model in this study can be seen in the members of the majelis ta'lim. They can find priority needs for children and their families, solve the most fundamental and pressing problems, and involve the wider community's interests. In community-based programs, the handling is not only for CCL, but also for larger interaction units: parents, entire family, peers, neighborhood, and wider social institutions.
Based on the research results, there are several suggestions:

1. The socialization regarding the law and CCL's problems, including those related to Law Number 11 of 2012 concerning the Juvenile Criminal Justice System, is still limited so that socialization of the community must be increased, particularly through majelis ta'lim.

2. The most common cause of children in conflict with the law is parental neglect, so intervention towards parents needs more attention. The Family Support Group must be developed through Family Development Session activities that are routinely carried out to focus on fulfilling children's rights.

3. Assistance to ABH must be provided to strengthen and socialize programs for them. Periodic assistance must be provided to strengthen and develop the service system

4. The developed model in this study is an alternative model in dealing with CCL problems.

\section{ACKNOWLEDGEMENT}

The author would like to thank all those who have contributed to this research, especially local governments who have permitted to research this location. Thanks also go to the informants, the heads of the majelis ta'lim who helped in the dissemination of the research questionnaire. Also, the authors would like to thank the Head of The Agency of Religious Research and Development of Makassar, the researchers and managers of the Al-Qalam journal who have given the author's confidence to become one of the authors in the publication.

\section{REFERENCES}

Adi, I.. 2013. Kesejahteraan Sosial (Pekerjaan Sosial, Pembangunan Sosial, Dan Kajian Pembangunan). PT Raja Grafindo Persada.

Burchinal, Margaret R., Deborah Lowe Vandell, and Jay Belsky. 2014. "Is the Prediction of Adolescent Outcomes from Early Child Care Moderated by Later Maternal Sensitivity? Results from the NICHD Study of Early Child Care and Youth Development." Developmental 
Psychology 50(2).

Chen, Chuan Yu, Carla L. Storr, Gung Mong Tang, Su Ling Huang, Chuhsing Kate Hsiao, and Wei J. Chen. 2008. "Early Alcohol Experiences and Adolescent Mental Health: A Population-Based Study in Taiwan." Drug and Alcohol Dependence 95(3).

Davies, Douglas. 2011. Child Development: A Practitioner's Guide (2nd Ed.).

Dutton, Jane. 2002. "Social Work Models, Methods and Theories." Child \& Family Social Work 7(1).

Garandeau, Claire F., and Antonius H. N. Cillessen. 2006. "From Indirect Aggression to Invisible Aggression: A Conceptual View on Bullying and Peer Group Manipulation." Aggression and Violent Behavior 11(6).

Gibbs, John C., Granville Bud Potter, Alvaro Q. Barriga, and Albert K. Liau. 1996. "Developing the Helping Skills and Prosocial Motivation of Aggressive Adolescents in Peer Group Programs." Aggression and Violent Behavior 1(3).

Golder, Seana, Andre Ivanoff, Richard N. Cloud, Karl L. Besel, Patrick McKiernan, Erica Bratt, and Linda K. Bledsoe. 2005. "Evidence-Based Practice with Adults in Jails and Prisons: Strategies, Practices, and Future Directions." Best Practice in Mental Health 1(2).

Hearn, Jody Lynn. 2010. "Family Preservation in Families' Ecological Systems: Factors That Predict out-of-Home Placement and Maltreatment for Service Recipients in Richmond City." Dissertation Abstracts International, A: The Humanities and Social Sciences.

Holland, Sally. 2014. "Assessment in Child and Family Social Work." in Child \& Family Assessment in Social Work Practice.

Klostermann, Keith C., and William FalsStewart. 2006. "Intimate Partner Violence and Alcohol Use: Exploring the Role of Drinking in Partner Violence and Its Implications for Intervention." Aggression and Violent Behavior 11(6).

Kompas. 2008. "150.000 Anak Indonesia Jadi Korban Pelacuran.” Retrieved March 1, 2019(https://nasional.kompas.com/ $\mathrm{read} / 2008 / 11 / 14 / 06411845 /$. anak.indone sia.jadi.korban.pelacuran).
Laser, Julie Anne, and Nicole Nicotera. 2011. "Working with Adolescents: A Guide for Practitioners." Social Work Practice with Children and Families. (March).

Maguire, Mandy J., Hirsh-Pasek Kathy, Golinkoff Roberta Michnick, and Amanda Brandone. 2008. "Focusing on the Relation: Few Exemplars Facilitate Children's Initial Verb Learning and Extension." Developmental Science 11(4):628-34.

Mohan, Brij. 2010. "Book Review: T. Mizrahi \& Larry L. Davis The Encyclopedia of Social Work (20th Ed.). Washington, DC, and New York: NASW Press and Oxford University Press, 2008. 2208 Pp., List Price \$495; NASW Member Price \$395, ISSN 0071-0237; ISBN 978-0-19530661-3 (Hardcover)." Research on Social Work Practice 20(2).

Muslim, A. 2011. Ekspresi Kebijaksanaan Masyarakat Bugis Wajo Memelihara Anak (Analisis Sastra Lisan). Al-Qalam, 17(1), 125-132.

Republika.co.id. 2014. "Komnas PA: Indonesia Darurat Kejahatan Seksual Terhadap Anak." Retrieved (https://www.republika.co.id/berita/ney 4lh/komnas-pa-indonesia-daruratkejahatan-seksual-terhadap-anak).

Rosen, Aaron. 1994. "Knowledge Use in Direct Practice." Social Service Review 68(4).

Setiawan, Hari Harjanto, and Sunusi Makmur. 2015. "Pengembangan Model Alternatif Menangani Anak Yang Berhadapan Dengan Hukum Berbasis Masyarakat Di Kelurahan Cipinang Besar Utara, Jakarta Timur." Sosio Konsepsia 4(3):142-59.

Sulhin, I. 2011. "FILSAFAT (SISTEM) PEMASYARAKATAN.” Jurnal Kriminologi Indonesia 7(1).

Walker, Gill, and Wendy Bryant. 2013. "Peer Support in Adult Mental Health Services: A Metasynthesis of Qualitative Findings." Psychiatric Rehabilitation Journal 36(1).

Ward, Alexander, Brizeida HernándezSánchez, and Jose C. Sánchez-García. 2019. "Entrepreneurial Intentions in Students from a Trans-National Perspective." Administrative Sciences 9(2). 